\title{
Buca Hasanağa Bahçesi'nin kullanım sürecinde mekânsal analizi
}

\author{
Çiğdem KILIÇASLAN1 ${ }^{1}$ Emine MALKOÇ TRUE²
}

${ }^{1}$ Adnan Menderes Üniversitesi Ziraat Fakültesi Peyzaj Mimarlığı Bölümü 09100 Koçarlı, AYDIN

${ }^{2}$ Ege Üniversitesi Ziraat Fakültesi Peyzaj Mimarlığı Bölümü 35100 Bornova, İZMİR

Alınış tarihi: 25 Temmuz 2017, Kabul tarihi: 09 Şubat 2018

Sorumlu yazar: Çiğdem KILIÇASLAN, e-posta:c.kilicaslan@hotmail.com

\section{$\ddot{0} \mathbf{z}$}

Parklar, içerisinde yer aldıkları yerleşimler için vazgeçilmez olup kentsel yaşam kalitesine katkıları yönüyle oldukça önemlidir. Sahip oldukları çok yönlü işlevleriyle büyük kentlerde birer çekim noktasına dönüşen bu mekânların üretiminde, özellikle planlama aşamasından başlayarak tasarım ve uygulama aşamalarında da devam eden bazı yanlışlıklar bulunmakta, bu da mekânın performansını etkileyerek kullanım sürecinde tatminsizliklere sebep olmaktadır. Bu noktadan hareketle, önemli bir tarihi geçmişe sahip olan Hasanağa Bahçesi, çalışmanın ana materyalini oluşturmaktadır. Parkın araştırma alanı olarak seçiminde; Buca İlçesi için önemli bir açık alan olma özelliği ile kullanıcı ve aktivite çeşitliliği etkili olmuştur. Çalışmada görsel analiz araştırma yönteminden yararlanılmış, veri toplama aşamasında araştırıcı grubunun yanı sıra, Ege Üniversitesi Ziraat Fakültesi Peyzaj Mimarlığı Bölümü lisans öğrencileri ile mimarlık meslek disipliniyle yakından ilişkili peyzaj mimarı, şehir plancısı, endüstri mühendisi, inşaat mühendisi vb. gibi farklı uzmanlıklara sahip kişilerin de değerlendirmelerine yer verilmiştir. Araştırma alanı; genel özelikleri, rekreasyonel, eğitsel, sosyal ve kültürel işlevleri yönleriyle analiz edilmiş, elde edilen rakamsal verilerden hareketle söz konusu mekânın kullanım kararlarını ve tasarımını yönlendirecek öneriler geliştirilmiştir. Çalışma sonucunda, araștırma alanının mekânsal açıdan kısmen yeterli olduğu görülmüș özellikle mekân kullanımını daha da zenginleștirmek adına bazı öneriler getirilmiştir.
Anahtar kelimeler: Hasanağa Bahçesi, mekânsal analiz, park, İzmir

\section{Spatial analysis of Buca Hasanağa Garden in the post occupancy process}

\begin{abstract}
Parks are indispensable places for the settlements where they are located and are very important in terms of their contribution to the quality of urban life. There are some inaccuracies in the production of these spaces, which have become points of attraction in the big cities with their multifunctional functions, especially starting from the planning phase and continuing in the design and application phases This causes the dissatisfaction in the usage process by affecting the performance of the space. From this point, Hasanağa Garden, which has an important historical background, constitutes the main material of the work. In the selection of the park as a research area; the diversity of users and activities and its being an important open space for Buca was effective. A visual analysis research method was used in the study. In addition to the research group, Ege University Agriculture Faculty, Landscape Architecture Department students and landscape architects, urban planners, industrial engineers, construction engineers, and so on, closely related to the discipline of architecture, have also been included in the evaluations. The research area was analysed by general features as well as recreational, educational, social and cultural functions. Based on the numerical data obtained, suggestions were developed to guide the use decisions and design of
\end{abstract}


the space. As a result of the research, it has been found that the research area is partially sufficient in terms of spatial features, in particular, some suggestions have been made in order to enrich the use of the space.

Key words: Hasanağa Garden, spatial analysis, park, İzmir

\section{Giriş}

Parklar, çeşitli fonksiyonlardan oluşmuş kent dokuları (konut, endüstri, ticaret, eğitim vb.) arasında dinlenme ve eğlenmeye olanak sağlayan en önemli kentsel rekreasyon alanlarındandır (Uzun, 1993). Başka bir deyişle, kentlerin ilgi merkezleri olup hemen her insanın yararlanacağı rekreasyonel olanak ve tesislere sahip yeșil alanlardır (Özkan, 1981). Park için yapılan tanımlar incelendiğinde, genel olarak park alanlarının, insanların yaşam süreçleri içerisinde nefes aldığı alanlar olarak ön plana çıarıldı̆̆ı görülmektedir. Parklar, yoğun çalışma ve yaşam mücadelesi içerisinde bireyin kendisi için de bir şeyler yapmasına olanak sağlayan, bireyi rahatlatan, mutlu eden, doğayla iç içe olmasını sağlayan, farklı fonksiyonları bir arada barındıran, çeşitli aktivitelerin yapıldığı alanlardır (Kandemir, 2010). Parklar, 18. yy.da gerçekleşen sanayileşme ve hızlı kentleşme sonucu oluşan sağlıksız ve parçalanmış kentsel çevrelere bir tepki olarak 19 yy.da batıda ortaya çıkmıştır (Koh and Beck, 2013).

Parklar, uzun yıllardır kentsel yerleşimlerin fiziksel ve estetik kalitesine katkı sağlayan en önemli mekânlar olarak tanımlanmıșlardır. Ancak son yıllarda parklar ile ilgili olarak yeni bir bakış açısı ortaya çıkmış olup, bu bakış açısı, politikacıların, uygulayıcıların ve toplumun, parkların iş olanakları, gençliğin gelişimi, toplum sağlığı ve toplumsal yapılaşma gibi büyük ölçekteki politikalar geliştirebilmesi yönünde taşıdığı önem üzerinde durmaları gerektiğine odaklanmaktadır (Walker, 2016).

Önder ve Polat (2012); "Kentsel Açık - Yeșil Alanların Kent Yașamındaki Yeri ve Önemi" bașlıklı çalışmalarında, kentsel açık - yeşil alanların ekonomik işlevlerinden bahsetmekte, turizm ve iș imkânı sağlama yararına değinmektedir. Ayrıca aynı çalışmada yeşil alanların sosyal işlevlerine değinilmekte, eğitim ve kültürel faaliyetlere imkân sağlama, suç oranını azaltma, toplumsal gelişmeye katkıda bulunma ve kamu sağlığını koruma işlevleri gündeme getirilerek yukarıda sözü edilen bakış açısı desteklenmektedir.

Parklar farklı görüşte insanları bir araya toplayan demokratik "ortaklıklar" olup insan sağllı̆ı, çevre ve finans konularını teşvik ederek son yıllarda giderek yok olan toplumsal ve sosyal canlllı duygusunu arttırmaktadır (Loures et al., 2007).

Demir (2006); "Toplumsal Değişme Süreci İçinde Gençlik Parkı: Sosyolojik Bir Değerlendirme” başlıklı çalışmasında, Ankara Gençlik Parkı örneğinden yola çıkarak park kullanma olgusunu açılamakta ve günümüzde yeni kentlilerin / kent yoksullarının kenti tanımalarında ve rekreasyon olanaklarından yararlanmalarında belli bir ișlevi üstlendiğini vurgulamaktadır.

Uyanık (2016); "Yeni Kent Kurgusunda Rekreatif Yeşil Alanlar ve Parklar Üzerine Sosyolojik Bir Araştırma" başlıklı çalışmasında, rekreasyona duyulan ihtiyacın demokratik bir toplumun yaratılmasına imkân sağladığından bahsetmekte, kamusal mekânların dolayısıyla önemli kamusal mekânlardan bir tanesi durumunda olan parkların, toplumsal yaşamın oynandığı bir sahne olarak tasarlandığı vurgulanmaktadır

Parklar, bulundukları kent bölümü, kapladıkları alan büyüklüğü, içerdikleri rekreasyonel olanak ve tesisler ile hizmet verdikleri alanın çeşitli özelliklerine göre;

Cep parki

Mahalle parkı,

Semt parkl,

Kent parkl,

Bölge parkı biçiminde sınıflandırılmaktadır (Özkan, 2001).

Semt parkları kullanıcılara uygun aktiviteleri sağlayan, rekreasyonel faaliyetlere imkân sunan parklardır. Merkeze yakın, ara yollara bağlantısı bulunmaktadır. Aktiviteler olarak takım veya bireysel sportif faaliyetler sunar. Geniş oyun alanları, basketbol, futbol gibi saha oyunları, su yüzeyleri, yürüyüş alanları ve genel açı alanlara sahiptir (Özkır, 2007).

Gold (1980)'a göre; semt parkları, kentsel nüfus tarafından gereksinim duyulan yakın rekreasyon olanaklarını destekler ve mümkün ise okullara bitişik olmalıdır. Semt parklarında, oyun alanları ve mahalle parklarında yer verilemeyen bazı rekreasyon kullanımlarına yer verilir. Semt parkı yoğun olarak gençler tarafından kullanılmaktadır. 
Gençlerin hareketliliklerinin fazla oluşu servis yarıçapının giderek artmasına neden olmaktadır. Semt parklarında tenis kompleksi, yüzme havuzu, çok amaçlı sahalar, sosyal merkez ve otopark gibi kullanımlar bulunabilir. Bu parklar için en iyi konum toplu taşım aksları üzeri ya da yakınıdır (Özkır, 2007).

Semt parkları birkaç mahalleye hizmet verecek parklardır. Aktif ve pasif rekreasyon etkinliklerine olanak sağlar. Hizmet yarıçapları 3000 metredir. 40200 dekar büyüklüktedir (Özkan, 2001). Yine Ertekin (1992)'e göre; semt parkları 1000-5000 arası konuta hitap etmeli ve 40-200 dekar arasında büyüklükte olmalıdır (Boyacl, 2010). Genel olarak semt parklarının Büyüklügü en az 40 da olmalı, bir tane önemli aktiviteyi bulundurmalı, en az 50 araçlık otoparkı olmalı, ulasılabilirlik uzaklığı 2-3 km olmalıdır (Whitfield, 2001).

Görsel analiz çalışmaları, bir yerin niteliğini ve görsel öğelerinin birbirleriyle olan etkileşimini algısal temelde belirlemeye yönelik çalışmaları kapsamakta olup fiziksel planlama, tasarım, uygulama ve bakım süreçlerine yönlendirici veri sağlama yönüyle önemli bir araçtır (Kaplan ve ark., 2000). Bu bağlamda, toplumsal yaşama ve içerisinde yer aldığı kente sağladığı yararlar temelinde, Buca Hasanağa Bahçesi'nin mekânsal analizini temel alan bu çalışma;

- $\quad$ Araştırma alanının genel özelliklerini ortaya koymak,

- Halkın bu mekânı kullanımına yönelik eğilimlerini saptamak,

- $\quad$ Parka ilișkin mekânsal değerlendirmelerde bulunmak,

- Kriterler yardımıyla mekânın kullanılabilirliğini değerlendirerek performansını belirlenmek,

- Yaşam kalitesini dolayısıyla mekânın çekim gücünü artırarak kamusal bir mekân olarak kullanımını zenginleștirmek,

- Yerel yönetimlere rehberlik etmek ve

- Benzer özellikli mekânların analiz ve değerlendirme çalışmalarına referans olması amacıyla gerçekleştirilmiştir.

\section{Materyal ve Yöntem}

\section{Materyal}

Genel kabul olarak Levantenler, ticaretle uğraşan, Avrupa'dan bu amaçla Anadolu'ya göç etmiş Avrupa kökenli insanların oluşturduğu topluluktur.
Yabanclara tanınan imtiyazlarla birlikte Levantenlerin etkileri ekonomik ve sosyal yaşamla birlikte fiziksel çevrede de kendisini göstermiştir (Açık Güneş, 2010). Genelde İngiliz, İtalyan, Fransız ve Hollandalı olan bu azınlıklar Osmanlı döneminde önemli ticaret merkezi olan İzmir'e gelerek yerleşmişler ve ticari faaliyetlerine de buradan yürütmüşlerdir. İzmir'e gelen Levantenler İzmir'in özellikle Bornova ve Buca semtlerini tercih etmişler, yaşantılarını ve ticari hayatlarını da bu iki merkezden yürütmeye başlamışlardır (Özeker, 2011). İzmir'in $9 \mathrm{~km}$. güney doğusunda bir plato üzerinde kurulmuş olan Buca banliyösü kendine özgü ilginç özelliklere sahiptir. Üstelik benzer pek çok yerleşmenin aksine bir transit yolu üzerinde olmasının verdiği avantajla fiziksel özelliğini halen korumaktadır (Erpi, 1987). Zengin bir ekonomi, zengin bir kültür çeșitliliği Buca'da zengin ve zevkli bir kent dokusu meydana getirmiştir. $\mathrm{Bu}$ doku, Buca'nın elverişli doğal ortam koşullarıyla bütünleştirilmiş Levanten ve Rumlara özgü malikâne, ev ve dini nitelik taşıyan yapıları ortaya çıkarmıştır (Oban Çakıcıoğlu, 2006). Buca'ya yerleșen Levanten aileler Buca'yı bir sayfiye beldesi olarak görmüşler, yeni mimari tarzları ile Buca'da önemli tarihi yapıları da ortaya koymuşlardır (Özeker, 2011). Geniş araziler içinde konumlanmış Levanten konutlarının, dışa kapalı, ulaşılmaz, ayrıcalıklı ifadelerini sağlayan temel faktörlerden biri içinde yer aldıkları arazi, peyzaj tasarımı, arazi sınırlama elemanları ve gösterişli giriş kapılarıdır. Konutların bahçelerinde gözlenen temel elemanlar; havuzlar, bu havuzları süsleyen gösterişli fiskiyeler ve/veya heykeller, kameriye ve gazebolar, pik döküm aydınlatma elemanlarıdır. Söz konusu peyzaj tasarımlarında kullanılan mimari öğelerin yanı sıra çiçek tohumlarının ve ağaçların da büyük bir kısmı Avrupa'dan getirtilmiştir. Bornova ve Buca Levanten konutlarının bahçelerinde kullanıcının ulusal kimliğinin belirleyici rolü dikkat çekicidir. Buca'da yer alan Baltazzi ve Aliberti konutlarındaki özgün tasarımlarda olduğu gibi, İtalyan kullanıcılara ait arazilerin net geometrilerle bölünmüș olduğu, havuz, kameriye, heykel gibi elemanların aksiyel düzenlemeler üzerine oturtulduğu saptanmaktadır. İtalyan bahçelerinde gözlenen bir diğer özellik, yoğunlukla dut ağacı sıraları, bazı bölümlerde ise bodur bitkilerle tanımlanmış yürüyüş aksları, promenatlardır. Doğaya ve kırsal alanlara düşkün tutumları ile tanınan İngiliz topluluğun bahçelerinde ise, arazi içinde ormansı bir hava yaratan, belli 
geometrilere oturmayan bir anlayışla kurgulanmış koruluk ve ağaç dizileri ön plandadır (Akkurt, 2004).

Araştırma alanı bir Levanten köşkünün bahçesi olup İzmir Kenti Buca İlçesi sınırları içerisinde yer alan Hasanağa Bahçesi'dir (Şekil 1 ve Şekil 2). 107.615 $\mathrm{m}^{2}$ 'lik alana yayılan Hasanağa Bahçesi'nin ilk sahibi İtalyan Levanten işadamı Aliotti'dir (İzmir Kültür ve Turizm Dergisi, 2009). Aliotti'nin ölümü üzerine mülk varisleri tarafından satılığa çıkarılmış ve 1926 yılında Ödemiş eşrafından Sarıgöllü Hasanağa tarafından satın alınmıștır (Erpi, 1987). Hasanağa, biri bahçenin kuzey, diğeri güneybatı köşesinde iki konut inşa ettirmiş, esas köşk ile diğer servis lojmanlarını ve bağ köşkünü konut olarak kiraya vermiş̧ir. 1930'lu yılların başlarında sigortalı olan köşk yanmıștır. Bahçe, Hasanağa ailesinin mülkiyetinde bulunduğu sürede halka açlk tutulmuş, Bucalılar için bir mesire yeri olarak kullanılmış ve Hasanağa Bahçesi olarak adlandırılmıştır. 1930'lu yıllarda verandalı müstakil bir ahşap konut, hizmetliler için tek katlı konutlar dizisi, bir bağ köşkü, konut büyüklüğünde bir kuş kafesi, çimento ve demir kullanılarak taş ve ahşap taklit edilerek yapılmış stalaktitli grottolar, kaskatlar içeren bir havuz kompozisyonu, kameriyeler, havuzlar dikkatle tasarlanmış bahçe içine dağıtılmıştır. Çoğu çam olan ağaçların yerleştirilmesinde de aynı dikkat gözlenmektedir. Bahçeyi batıdan doğuya kesen çizgisel bir yolun iki yanındaki dut ağaçlarının özel yetiştirilmesi ile yarı saydam bir tünel şeklindeki promenada dönüştürülmüş dut ağaçları günümüzde mevcut değildir (İzmir İl Kültür ve Turizm Müdürlüğü, 2017). İlk adı Aliotti bahçesi olan Hasanağa Bahçesi'nin ilk genel düzeninde Anglo Sakson yaklaşımdan farklı olarak Latin Avrupa anlayışı egemendir. Aliotti malikanesi Buca'daki malikaneler içinde alan olarak en geniş bahçeye sahip olanıdır (Erpi, 1987). Çizgisel dolaşım aksları, doğal malzemeden yapay düzenlemeler veya yapay malzemeden doğal görünüm arayışları bu anlayışın yansımaları olarak kaydedilebilir. Benzer türde bahçe düzeni anlayışına İstanbul Emirgan korusunda rastlanmaktadır. Aliotti'nin bu geniş araziyi doğal çevre görünümünde bir hayvanat bahçesi haline getirdiği, geyik, tavus vb. hayvanların yüksek duvarlarla çevrili bahçe içinde serbestçe dolaştıkları ve 1930'lara kadar bahçenin bu hâlini muhafaza ettiğini eski Bucalılar hatırlamaktadır (İzmir ìl Kültür ve Turizm Müdürlüğü, 2017). Günümüzde de halen önemini korumakta olan alan, Özkan (2001)'e göre hizmet yarıçapı bakımından semt parkı niteliğindedir. Hasanağa Bahçesi günümüzde belediye mülkiyetinde olup içerisinde çeşitli bitki ve hayvan türleriyle Buca halkının en önemli dinlenme yerlerinden biridir (Oban Çakıcıoğlu, 2006).

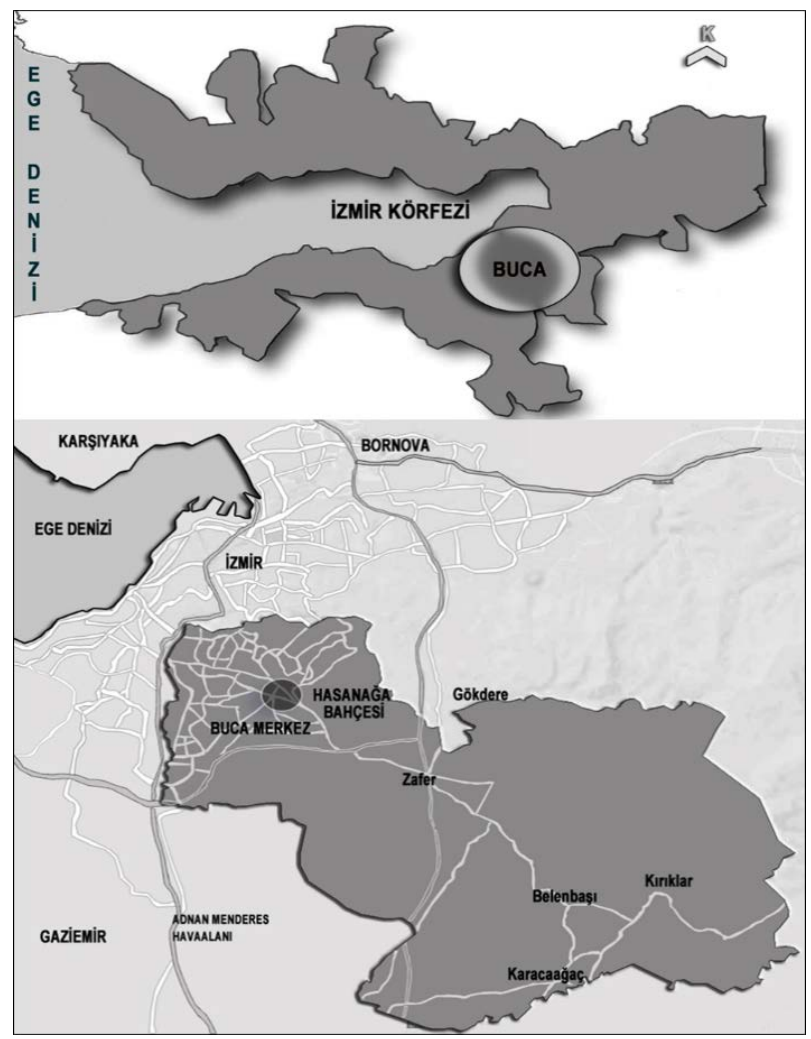

Şekil 1. Araştırma alanının konumu.
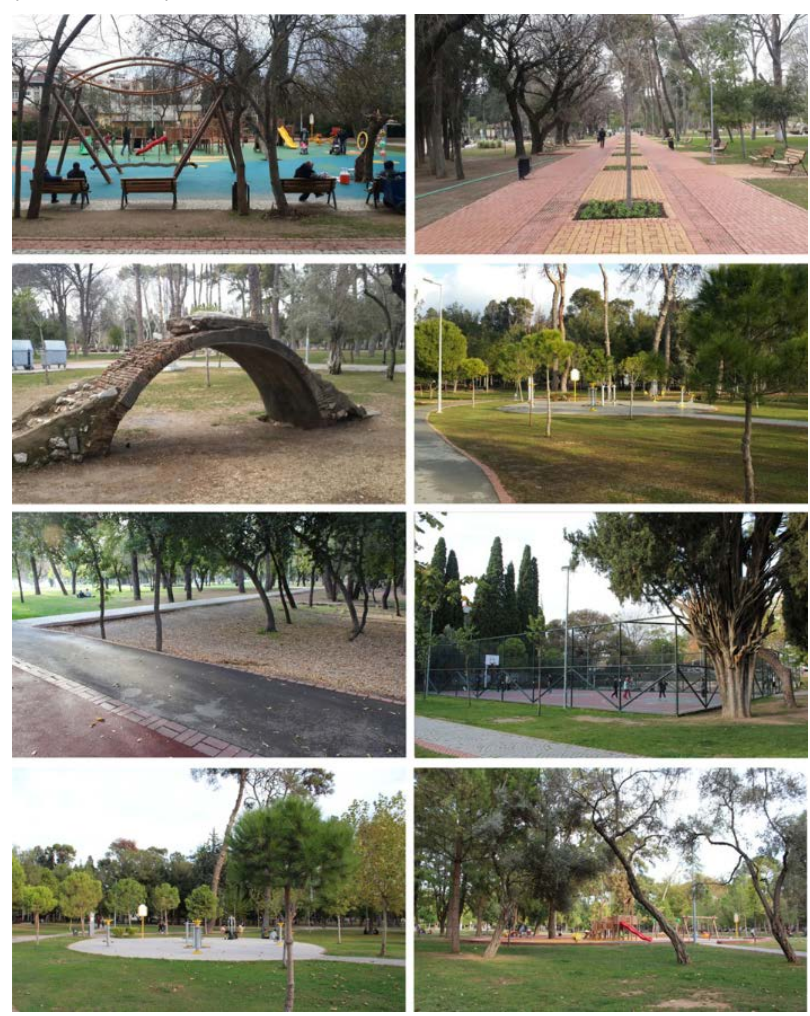

Şekil 2. Araștırma alanından fotoğraflar. 


\section{Yöntem}

Buca İlçesi açısından önemli bir tarihi geçmişe sahip olan Hasanağa Bahçesi'nin kullanım sürecinde mekânsal analizi bu çalışmanın çıkış noktasını oluşturmaktadır. Hasanağa Bahçesi bu çalışmada araştırma alanı olarak seçilmiş ve mekânsal yeterliliği sorgulanmıştır. Araştırma başlıca 4 aşamadan oluşmaktadır (Şekil 3):

-Kavramsal Çerçeve: $\mathrm{Bu}$ așama; araștırma alanının tarihi geçmişi ve mekansal özelliklerine ilişkin literatür çalışmalarıyla, mekanın nasıl kullandığını anlamaya yönelik arazi gözlem çalışmalarından oluşmaktadır.

-Veri Toplama: Çalışmada görsel analiz araştırma yönteminden yararlanılmış, Peyzaj Mimarlığı Bölümü Lisans son sınıf öğrencilerinden oluşan 10 kișilik bir grup (Öğrenci Grubu) ile içerisinde yazarların da bulunduğu peyzaj mimarı, șehir plancısı, endüstri mühendisi, inşaat mühendisi vb. mimarlık meslek disipliniyle ilgili uzmanlardan oluşan 10 kişilik bir gruptan (Uzman Grubu) destek alınmıştır. Öğrenci ve uzman grup araştırma alanını yerinde incelemiş ve gerçekleştirdiği gözlemleri takiben kendilerine sunulan önceden hazırlanmış mekansal analiz formu aracılığıyla alanı değerlendirmiştir. Mekansal analiz formunun hazırlanmasında araştırma ekibinin yaklaşımları ile Özkan ve ark (2003), Küçükerbaş ve ark (2013), Kılıçaslan ve ark (2016) yararlanılmıştır.

Çalıșma için özgün olarak hazırlanmıș olan mekânsal analiz formu 2 ana bölümden oluşmuştur. İlk bölümde, mekânın genel özellikleri (büyüklüğü, tipi, çevre yapılaşma durumu) saptanmış, rekreasyonel işlevler (çocuk oyun alanı, spor alanı, kay - kay pisti, dinlenme - oturma alanı, su yüzeyleri, yürüyüş yolu, bisiklet yolu) ile eğitsel - sosyal - kültürel işlevler (hayvan barınakları, çeşme, sıhhi olanaklar, otopark, plastik elemanlar, bisiklet park yeri) "yeterli", "kısmen" ve "yetersiz" olacak şekilde değerlendirilmiştir.

İkinci bölümde ise; araștırma alanı; mekanın organizasyonu, ekolojik özellikleri, bitkisel tasarım, mimari özellikleri, erişim, güvenlik, donatı, sosyalleşmeye katkısı, mekan kullanımı alt başlıklarında yer alan 32 alt kriter yardımıyla "1 en olumsuz", "4 en olumlu" olacak şekilde "1-4" arasında puanlanmıştır.

Puanların analizi aşamasında, birinci bölümde, öğrenci ve uzman grup tarafından, her bir kriter için verilen puanların yüzde karşılıkları hesaplanmıştır.
İkinci bölümde ise, yine öğrenci ve uzman grup tarafından her bir kriter için verilen puanların kriter ortalamaları hesaplanmış, kriter ortalamaları temel alınarak, öğrenci-uzman ortalaması ve genel ortalamalara ulaşılmıştır. Öğrenci ve uzman kriter ortalamalarının hesaplanmasında, her bir kriter için öğrenci veya uzman tarafından verilen puanların yüzde karşılıklarının maksimum 4 olabilecek olan yeterlilik puanı içindeki etki değeri bulunmuş bu sayede öğrenci ve uzman için ortalama ile genel ortalamaya ulaşılmıştır. Ortalama değerleri 1.002.00 puan aralığındaki kriterler "yetersiz", 2.01-3.00 puan aralığındaki kriterler "kısmen yeterli" 3.014.00 puan aralığındaki kriterler yeterli olarak değerlendirilmiştir.

-Araştırma Bulguları: Literatür çalışmaları, arazi etüt ve gözlemleri ve analiz çalışmalarından elde edilen bulgular mekânsal yeterlilik temelinde değerlendirilmiştir.

-Sonuç ve Öneriler: Değerlendirmeler sonucunda; analiz sonuçlarında da yararlanılarak araștırma alanının yeterliliği tartışılmış, mevcut mekân kullanımındaki aksayan yönler belirlenmiș ve mekan kullanımını geliştirilmek adına strateji ve öneriler üretilmiştir.

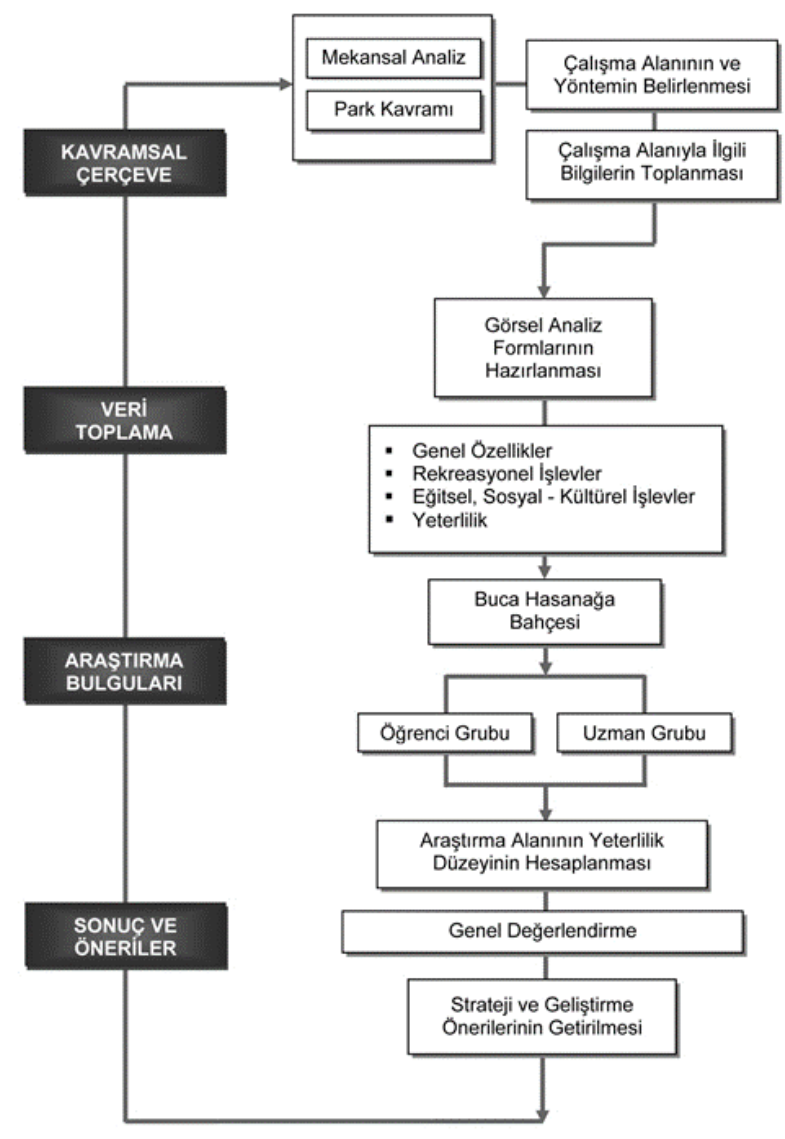

Şekil 3. Yöntem akış şeması. 


\section{Bulgular}

Bu çalışmada; İzmir ili Buca İlçesi sınırları içerisinde yer alan Hasanağa Bahçesi'nin kullanım sürecinde mekânsal açıdan analizi gerçekleştirilmiştir. Uzman ve öğrenci grupları tarafından "Mekânın genel özellikleri" ve" Mekânsal analizler" alt başlıkları altında belirlenen kriterler yardımıyla araştırma alanı analiz edilmiş ve bulgular elde edilmiştir.

Çizelge 1. Mekânsal analiz formu I (mekânın genel özellikleri)

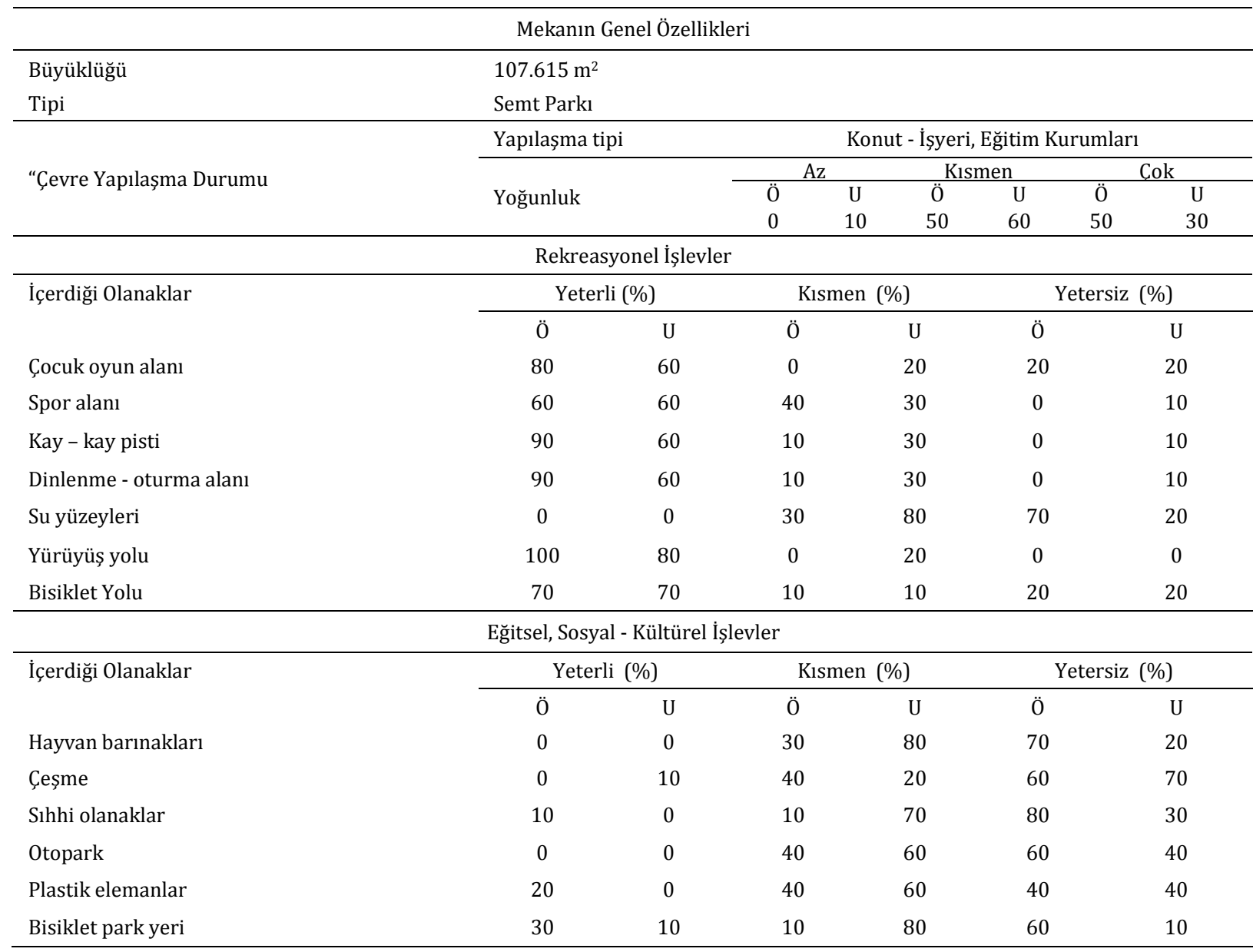

\section{Mekânın genel özellikleri}

Mekânsal analizlerde öncelikle araştırma alanının genel yapısı ortaya konulmuştur (Çizelge 1). Araştırma alanı $107.615 \mathrm{~m} 2$ büyüklüğünde bir semt parkı olup; kuzeydoğusunda Dokuz Eylül Üniversitesi Dokuz Çeşmeler Yerleşkesi, Kuzeybatısında ise Buca Fen Lisesi, Buca İlköğretim Okulu ve Buca Fatma Saygın Anadolu Lisesi gibi eğitim kurumlarıyla çevrelenmiştir. Araştırma alanının çevresindeki yapılaşma durumu; öğrenci (\% 50) ve uzman grup (\% 60) tarafindan genelde kısmen yoğun bulunmuştur.

\section{Mekânın rekreasyonel işlevleri:}

Araştırma alanı; çocuk oyun alanları, spor alanları, kay - kay pisti, dinlenme - oturma alanları, su yüzeyleri, yürüyüş ve bisiklet yolları gibi olanakları içermektedir. Araştırma alanı rekreasyonel işlevlere yönelik içerdiği olanaklar yönüyle irdelendiğinde; su yüzeyleri dışında uzman ve öğrenci grubu tarafından genelde yeterli bulunmuştur (Çizelge 1). Uzman grup su yüzeylerini $\% 80$ oranında "kısmen yeterli" olarak değerlendirirken, öğrenciler \%70 gibi bir oranla yetersiz bulmuştur. Çalışma alanı içersideki yürüyüş yolları ise hem uzman hem de öğrenci grubu tarafından yeterli düzeyde bulunmuştur (Sırasıyla $\% 100$ ve $\% 80$ ).

\section{Eğitsel, sosyal - kültürel işlevleri}

Araştırma alanı; hayvan barınakları, çeşme, WC gibi sihhi olanaklar, otopark, plastik elemanlar ve bisiklet park yerleri içermektedir. Bu işlevler, genelde uzman grup ve öğrenciler açısından kısmen yeterli veya yetersiz olarak değerlendirilmiş ve geliştirilmesi 
gerekliliği tespit edilmiştir. Özellikle uzman grup hayvan barınaklarını (\% 80), sıhhi tesisleri (\% 70) ve bisiklet park yerlerini (\% 80) yüksek oranda kısmen yeterli olarak değerlendirirken, öğrenci grubu yetersiz olarak değerlendirmiştir (Hayvan barınaklarını (\% 70), sıhhi tesisleri (\% 80) bisiklet park yerleri (\% 60)). Uzman grup tarafından çalışma alanı içersinde yer alan çeşme sayısı ise büyük çoğunlukla yetersiz olarak değerlendirilmiştir (\%70) (Çizelge 1).

Çizelge 2. Mekânsal Analiz Formu II (Mekânsal Yeterlilik)

\begin{tabular}{|c|c|c|c|c|c|}
\hline & Yeterlilik & ÖKO & UKO & ÖUO & GO \\
\hline \multirow{5}{*}{$\begin{array}{l}\text { Mekânın } \\
\text { Organizasyonu }\end{array}$} & Farklı işlevler üstlenmiş alanlar arasında tampon görevi görme & 2.1 & 2.2 & 2.15 & \multirow{5}{*}{2.52} \\
\hline & Mekân içi organizasyonun başarısı & 2.5 & 2.0 & 2.25 & \\
\hline & Yakın çevre ile fiziksel ilişki derecesi & 3.3 & 2.2 & 2.75 & \\
\hline & Çevreden algllanma derecesi / görülebilirliği & 3.4 & 3.4 & 3.4 & \\
\hline & Alt mekân içerme & 2.5 & 1.6 & 2.05 & \\
\hline \multirow{2}{*}{$\begin{array}{l}\text { Ekolojik } \\
\text { Özellikler }\end{array}$} & Bitki çeşitliliği zenginliği & 2.5 & 2.6 & 2.55 & \multirow{2}{*}{2.68} \\
\hline & Klimatik etkisi & 2.8 & 2.8 & 2.8 & \\
\hline \multirow{5}{*}{$\begin{array}{l}\text { Bitkisel } \\
\text { Tasarım }\end{array}$} & Gölgeleme & 2.7 & 3.0 & 2.85 & \multirow{5}{*}{2.34} \\
\hline & Perdeleme & 2.4 & 2.8 & 2.6 & \\
\hline & Fon oluşturma & 2.6 & 2.4 & 2.5 & \\
\hline & Sınırlandırma - kuşatma & 2.0 & 2.4 & 2.2 & \\
\hline & Gürültüyü önleme & 1.9 & 1.2 & 1.55 & \\
\hline \multirow{3}{*}{$\begin{array}{l}\text { Mimari } \\
\text { Özellikleri }\end{array}$} & Çevre kalitesine / imajına olumlu katkı sağlama & 3.0 & 3.2 & 3.1 & \multirow{3}{*}{2.27} \\
\hline & Tasarımın orijinalliği / ilgi çekiciliği & 1.8 & 2.2 & 2.0 & \\
\hline & Gece kullanımını teşvik etme & 2.0 & 1.4 & 1.7 & \\
\hline \multirow{6}{*}{ Erişim } & Mekân girişinin netliği & 2.0 & 2.2 & 2.1 & \multirow{6}{*}{2.69} \\
\hline & Toplu taşıma araçlarıyla erişim kolaylığı & 3.9 & 3.6 & 3.75 & \\
\hline & Mekân içi dolaşımın başarısı & 3.5 & 2.8 & 3.15 & \\
\hline & Mekân içi aydınlatma & 2.6 & 1.6 & 2.1 & \\
\hline & Yürüme emniyeti & 3.1 & 1.8 & 2.45 & \\
\hline & Yürüme konforu & 3.0 & 2.2 & 2.6 & \\
\hline \multirow{2}{*}{ Güvenlik } & Psikolojik güvenlik & 2.1 & 1.2 & 1.65 & \multirow{2}{*}{1.78} \\
\hline & Fiziksel güvenlik & 2.2 & 1.6 & 1.9 & \\
\hline \multirow{2}{*}{ Donatı } & Yapısal donatı & 2.4 & 1.8 & 2.1 & \multirow{2}{*}{2.4} \\
\hline & Bitkisel donatı & 2.6 & 2.8 & 2.7 & \\
\hline \multirow{4}{*}{ Sosyalleşmeye Katkısı } & Farklı yaş gruplarına hitap etme & 3.7 & 2.6 & 3.15 & \multirow{4}{*}{3.15} \\
\hline & Toplumun farklı kesimlerini bir araya getirme & 3.8 & 2.2 & 3.0 & \\
\hline & Grup kullanımına uygunluk & 3.8 & 2.4 & 3.1 & \\
\hline & Buluşma yeri olma özeliği & 3.9 & 2.8 & 3.35 & \\
\hline \multirow{3}{*}{$\begin{array}{l}\text { Mekân } \\
\text { Kullanımı }\end{array}$} & Tüm alt bölümlerin kullanımı & 3.0 & 2.0 & 2.5 & \multirow{3}{*}{2.1} \\
\hline & Kullanımı etkileyen çevresel etmenlerin varlığı & 2.1 & 2.2 & 2.15 & \\
\hline & Olumsuz iklim etmenlerinden korunma olanağı & 1.1 & 2.2 & 1.65 & \\
\hline
\end{tabular}

\section{Mekânsal Analizler}

$\mathrm{Bu}$ aşamada, Çizelge 2'de belirtilen mekanın organizasyonu, ekolojik özellikleri, bitkisel tasarımı, mimari özellikleri, erişim, güvenlik, donatı, sosyalleşmeye katkısı, mekan kullanımı kriterleri, "1 en olumsuz", "4 en olumlu” olacak șekilde uzman ve öğrenci grubu tarafindan "0-4” arasında puanlanmış ve elde edilen değerlerden öğrenci ve uzman kriter ortalamaları hesaplanmıştır (ÖKO ve UKO). Her bir kriter için öğrenci veya uzman tarafından verilen puanların yüzde karşılıklarının maksimum 4 olabilecek olan yeterlilik puanı içindeki etki değeri bulunmuș bu sayede öğrenci ve uzman için ortalama (OUO) ile genel ortalamaya (GO)ulaşılmıştır. 
Buna göre; en yüksek ÖKO değerlerini; "Toplu taşıma araçlarıyla erişim kolaylığı" (3.9) ve "Buluşma yeri olma özelliği” (3.9) alırken, en düşük ÖKO değerini "Olumsuz iklim etmenlerinden korunma olanağı" (1.1) almıştır. Belirtilen değeri sırasıyla "Park tasarımın orijinalliği / ilgi çekiciliği" (1.8) ve bitkilerin gürültüyü önleyebilme düzeyi (1.9) almıştır.

En yüksek UKO değeri benzer şekilde; “Toplu taşıma araçlarıyla erişim kolaylığı" (3.6) olarak belirlenmiștir. En düșük UKO değerleri ise, bitkilerin "Gürültüyü önleme" ișlevi (1.2) ve alanın "Psikolojik güvenlik" (1.2) açısından yeterliliği olarak görülmektedir. Yine parkın "Gece kullanımını teşvik etme" (1.4) özelliğinin uzmanlar tarafından yetersiz olarak bulunduğu görülmektedir. Parkın farklı alt mekân içerme, aydınlatma ve fiziksel güvenliğine ilişkin kriterler yönüyle de 1.6 gibi bir değer aldığı ve yeterli düzeyde olmadığı belirlenmiştir.

Öğrenci ve uzman ortalamaları irdelendiğinde; "Toplu taşıma araçlarıyla erişim kolaylığı” 3.75 gibi bir ortalamayla oldukça yüksek düzeydedir. Buna karșın bitkilerin gürültüyü önleme özelliğine ilișkin ortalama, 1.55 gibi bir değerde olup oldukça düşüktür. Çalışma alanı; psikolojik güvenlik (Ortalama 1.65) ve olumsuz iklim etmenlerinden korunma olanağı (Ortalama 1.65) açısından da oldukça yetersiz olarak belirlenmiştir.

Genel ortalamalar göz önünde bulundurulduğunda; araştırma alanının insanların sosyalleşmesine katkısı açısından oldukça başarılı olduğu (Ortalama 3.15) belirlenmiş, bunu erişim açısından yeterlilik (ortalama 2.69) ve bitkilerin ekolojik özellikleri (Ortalama 2.68) takip etmiştir. En düşük puanı ise alanın güvenliğine ilişkin kriter almıştır (Ortalama 1.78) (Çizelge 2).

\section{Sonuç ve Öneriler}

Araştırma alanı, İzmir Kenti ve Buca ilçesi açısından hem tarihi değeri ve kent kimliğine katkısı, hem de yoğun yapılaşma baskısı altında yaşayan kent halkı için merkezi konumu sayesinde nefes alabilecekleri bir ortam sağlaması nedeniyle vazgeçilmez niteliktedir. Buca ilçesinin merkezinde yeşil alanların sahip olduğu ekolojik işlevleri karşılayan, sosyal, kültürel, rekreasyonel olanaklar içeren Hasanağa Bahçesi her mevsim insanlar tarafindan yoğun olarak kullanılmaktadır. Gerçekleştirilen çalışmayla, kent için bu kadar öneme sahip bir parkın, mevcut mekân kullanımındaki aksayan yönleri belirlemek ve bu doğrultuda mekân kullanımını geliştirilmek adına bazı öneriler getirilmiştir.
Bulgulardan elde edilen sonuçlar değerlendirildiğinde;

Mekânın genel özelliklerine göre;

Araştırma alanı, ilk ve orta dereceli okullar ve üniversite yerleşkesiyle çevrelenmiş durumdadır. Park, konut alanları, özellikle öğrencilere yönelik yeme içme mekânları vb. iş yerleri ve Üçkuyular Meydanı arasında tampon görevi üstlenmekte, bu durum mekânın merkezi konumunu gözler önüne sermektedir.

Araştırma alanı birçok rekreasyonel, eğitsel, sosyal kültürel olanak içermekte bu da kullanımını arttırmaktadır. Bununla birlikte, bu kadar yoğun kullanılan bir parkın özellikle sıhhi olanaklar yönüyle geliştirilmesi gerektiği belirlenmiştir.

Alanda plastik elemanların varlı̆̆ı mekânı zenginleştirmektedir. Özellikle yakın çevredeki eğitim kurumları da düşünülerek, sosyal ve kültürel aktivitelere daha fazla olanak sağlayan, çeşitli etkinliklerin gerçekleştirileceği alanların (sergi alanları, konser vb. amaçlara yönelik alanlar) oluşturulması mekânın kullanım niteliğini olumlu yönde etkileyecektir.

Alanda farklı yaş gruplarına hitap eden çocuk oyun alanları oluşturulmuştur. Bununla birlikte çocuk oyun alanlarının zemininde kısmi bozulmalar söz konusudur. Özellikle kum havuzunun rutin bakımı gerçekleştirilmelidir.

Tavus kuşlarının içerisinde yer aldığı kafesler bulunmaktadır. Hayvanların daha rahat hareket edebileceği, özellikle çocukların eğitimine ve gelişimine de katkı sağlayacak şekilde tasarıma gidilmelidir.

Özellikle yürüyüş ve bisiklet yolu üzerinde çöp kutuları sayısal olarak arttırılmalı, alanda yer alan çeşme onarılıp kullanılır hale getirilmelidir. Alanda yönlendirme levhaları yer almakla birlikte, üzerindeki yazıların okunabilirliği arttırılmalı, uzaktan da okunabilecek yazı boyutları tercih edilmelidir.

Mekânsal yeterlilik analizlerine göre;

Araştırma sonucunda, araştırma alanının mekânsal açıdan genelde kısmen yeterli aralığında olduğu belirlenmiștir.

Alandaki mevcut ağaçlar mekân oluşumuna büyük katkı sağlamakta olup, mekânın kimliğinin oluşmasındaki en önemli faktördür. Alanda bitkisel tasarımı güçlendirecek şekilde yeni ağaçlar 
dikilmiștir. Bununla birlikte tasarıma renk getirilerek, mevsimsel farklılıklar vurgulanmalıdır.

Araştırma alanındaki yapısal elemanların seçiminde mekânın tarihi dokusu ve yaşanmışlığını hissettiren özgün tasarımlara yer verilmelidir. Seçilen malzemelerin birbiriyle uyumlu olması da sağlanmalı, donatı elemanlarının seçiminde konsept bütünlüğüne gidilmelidir.

Araștırma alanında olumsuz iklim etmenlerinden korunmaya yönelik önlemlerin alınması gerektiği belirlenmiştir. $\mathrm{Bu}$ nedenle gölgeleme, yağmurdan korunma vb. olanaklar sağlayacak yapısal donatı elemanlarına alanda yer verilmelidir.

Alanda çam ağaçlarının yoğun olarak bulunması nedeniyle ağaçların altındaki çim alanlarda yer yer bozulmaların olduğu görülmektedir. Bu nedenle çim alanların bakımı düzenli olarak gerçekleştirilmeli, uygun olan alanlarda çim alanlar diğer yer örtücü bitkilerle değiștirilmelidir.

Araştırma alanında, özellikle güvenliğe (Genel ortalama;1.78) yönelik önlemlerin arttırılması gerektiği sonucuna ulaşılmıştır. Bunun temel nedenlerinden birisi aydınlatmanın yetersiz olmasıdır. Aydınlatmaya yönelik gerekli çalışmalar yapılmalıdır. Bunun yanında, yer döşemesindeki bozulmalar düzeltilerek yürüme konforu arttırılmalıdır.

Alanın sosyalleșmeye olan katkısı (Genel ortalama; 3.15) yönüyle oldukça başarılı bulunmuştur. Bununla birlikte çeşitli etkinliklere olanak veren, özellikle öğrencilerin gelişimine yönelik sosyal aktivitelere firsat tanıyan alt mekânların arttırılması, araştırma alanının kullanımını, dolayısıyla toplumun gelişimine katkı sağlayan nitelikli mekânların kullanımını arttıracaktır.

Alanda yer alan tarihi kalıntıların etrafı çevrelenerek koruma altına alınmıştır. Bununla birlikte içerisine çöplerin atıldığı ve izbe hale geldiği görülmektedir. Alanın temizlenmesine yönelik çalışmalar yapilmalidir.

\section{Kaynaklar}

Açık Güneş, G., 2010. Mersin Levanten Yapıları Üzerine Bir İnceleme. Çukurova Üniversitesi Fen Bilimleri Enstitüsü Mimarlık Anabilim Dalı Yüksek Lisans Tezi, Adana, $68 \mathrm{~s}$.

Akkurt, H., 2004. Batılı Kültürün 19. Yüzyıl İzmir'inde Mekansal Temsili Bornova ve Buca Levanten Konutları, EGEMIMARLIK 2004/3 - 51.
Boyacı, E., 2010. Ülkemizde Kent Parkı İşlevlerini Belirleyen Etmenler. Ankara Üniversitesi Fen Bilimleri Enstitüsü Yüksek Lisans Tezi, 107s.

Demir, E., 2006. Toplumsal Değişme Süreci İçinde Gençlik Parkı: Sosyolojik Bir Değerlendirme. Planlama, 4: 69-78.

Erpi, 1987. Buca'da Konut Mimarisi (1838-1934): Bir Yüzyıl Dönemini Kapsayan Mimari Oluşumun Sosyo -Kültürel Analizi ve Tipolojik Sentezi. O.D.T.Ü. Mimarlık Fakültesi Basım İşliği, 268 s.

İzmir İl Kültür ve Turizm Müdürlüğü, 2017. Buca. http://www.izmirkulturturizm.gov.tr/TR,77445/b uca.html, (Erişim Tarihi: 08.12.2017).

İzmir Kültür ve Turizm Dergisi, 2009. Tarih Kokan Büyülü Şehir İzmir. Kenardaki Güzellik -Hasanağa Bahçesi. İzmir Kültür ve Turizm Dergisi, Eylül - Ekim 2009, Yıl: 1 Sayl:1, S: 71-73, http://www.renklikalem. com.tr /old/izmir/izmir01/HTML/files/assets/ basic-html/page74.html, (Erişim Tarihi: 27.10.2016)

Kandemir, R.V., 2010. Kamusal Alan İçerisinde Mahalle Parkları ve Bir Mahalle Parkı Tasarım Rehberi Düşüncesi, Mimar Sinan Güzel Sanatlar Üniversitesi, Fen Bilimleri Enstitüsü, Şehir ve Bölge Planlama Anabilim Dalı, Yüksek Lisans Tezi, $124 \mathrm{~s}$

Kaplan A, Hepcan, S., Küçükerbaş, E., Özkan, B., 2000. Kuşadası Kent Merkezine Yönelik Bir Görsel Analiz Çalışması, Geçmişten Geleceğe Kuşadası Sempozyum Kitabı, Kuşadası, 23 - 26 Şubat 2000, Sayfa: 405 - 410.

Kılıçaslan, Ç., Deniz, B., Kara, B., Polat, Z., Göktuğ, T. H., Malkoç True, E., Kesgin Atak, B., 2016. Mekansal Yeterlilik Kapsamında Aydın Kentsel Alanındaki Parkların Analizi. Adnan Menderes Üniversitesi Ziraat Fakültesi Peyzaj Mimarlığı Bölümü, Proje No: ZRF - 11003, 114 s.

Koh, J., Beck, A., 2016. Parks, People and City, http://www.environmental-expert.com/Files\%5C1 9643\%5Carticles\%5C7617\%5C22s22-115227908 2.pdf, (Erişim Tarihi: 25.10.2016).

Küçükerbaș, EV., Özkan, M.B., Malkoç True, E., Sönmez Türel, H., Altuğ Turan, İ., Özeren, M., 2013. Bergama Kentsel Dış Mekanlarının Yeterliliği Üzerine Bir Araştırma, Ege Üniversitesi Ziraat Fakültesi Peyzaj Mimarlığı Bölümü, Proje No: 2011 - ZRF - 007, 191 s.

Loures, L., Santos, R., Panagopoulos, T., 2007. Urban Parks and Sustainable City Planning - The Case of Portimão, Portugal. Journal of Environment and Development, 3(10): 171-180. 
Oban Çakıcıoğlu, R., 2006. İzmir'in Eski Kentsel Dokusunun Korunması ve Turizm Açısından Değerlendirilmesi. Dokuz Eylül Üniversitesi Eğitim Bilimleri Enstitüsü Orta Öğretim Sosyal Alanlar Eğitim Anabilim Dalı Coğrafya Öğretmenliği Programı Doktora Tezi Bölümü, $345 \mathrm{~s}$.

Önder, S., Polat, A.T., 2012. Kentsel Açık - Yeşil Alanların Kent Yaşamındaki Yeri ve Önemi. Kentsel Peyzaj Alanlarının Oluşumu ve Bakım Esasları Semineri 19 Mayıs 2012, Konya, s: 73 - 96.

Özeker, O., 2011. İzmir'in Levantenleri. Sonsuzluk 25 Aralık 2011. http://blog.milliyet.com.tr/izmir-inlevantenleri/Blog/?BlogNo=340530, (Erişim Tarihi: 27.10.2016).

Özkan, B., 1981. Kıyı Rekreasyonunu Değerlendirme Ölçütleri ve Bunlara İlişkin Yöntemin Kuzey Ege Kıyılarında Uygulanması Üzerinde Araştırmalar. Ege Üniversitesi Ziraat Fakültesi Peyzaj Mimarlığı ve Süs Bitkileri Bölümü Doktora Tezi, İzmir.

Özkan, B., 2001. Kentsel Rekreasyon Alan Planlaması. Ege Üniversitesi Ziraat Fakültesi Peyzaj Mimarlığı Bölümü, Ders Notları, 79 s.

Özkan, B., Küçükerbaş, E. V., Kaplan, A., Hepcan, Ş., Malkoç, E., Yiğit, Sönmez, H., 2003. Muğla Kenti Kamusal Dış
Mekanları Bağlamında Master Plan Çalışması. ISBN: 975 - 93154 - 0 - 8, Ege Üniversitesi Basımevi, Şubat, 2003, Bornova, İzmir.

Özkır, A., 2007. Kent Parkları Yönetim Modelinin Geliştirilmesi. Ankara Üniversitesi Fen Bilimleri Enstitüsü, Peyzaj Mimarlığı Anabilim Dalı Doktora Tezi, Ankara, $176 \mathrm{~s}$.

Uyanık, H.N., 2016. Yeni Kent Kurgusunda Rekreatif Yeşil Alanlar ve Parklar Üzerine Sosyolojik Bir Araştırma. Selçuk Üniversitesi, Sosyal Bilimler Enstitüsü, Sosyoloji Anabilim Dalı, Sosyoloji Bilim Dalı, Yüksek Lisans Tezi, 108 s.

Uzun, G., 1993. Kentsel Rekreasyon Alan Planlaması. Çukurova Üniversitesi Ziraat Fakültesi Ders Kitabı No: 48, Adana, $100 \mathrm{~s}$.

Walker, C., 2016. The Public Value of Urban Parks, The Urban Institute - The Wallace Foundation, http://www.urban.org/uploadedpdf/311011_urba n_parks.pdf, (Erişim Tarihi: 25.10.2016).

Whitfield, D., 2001. Public Services or Corporate Welfare Rethinking the Nation State in the Global Economy. Pluto Press, ISBN: 074530855 4, 314 p. 